\title{
Growth curves for Turkish Girls with Turner Syndrome: Results of the Turkish Turner Syndrome Study Group
}

Feyza Darendeliler1, Ediz Yeşilkaya2, Abdullah Bereket3, Firdevs Baş1, Rüveyde Bundak1, Erkan Sarı2, Banu Küçükemre Aydın1, Şükran Darcan4, Bumin Dündar5, Muammer Büyükinan6, Cengiz Kara7, Mümtaz M. Mazıcıoğlu8, Erdal Adal9, Ayşehan Akıncı10, Mehmet Emre Atabek11, Fatma Demirel12, Nurullah Çelik13, Behzat Özkan14, Bayram Özhan15, Zerrin Orbak16, Betül Ersoy17, Murat Doğan18, Ali Ataş19, Serap Turan3, Damla Gökşen4, Ömer Tarım20, Bilgin Yüksel21, Oya Ercan22, Şükrü Hatun23, Enver Şimşek24, Ayşenur Ökten25, Ayhan Abacı26, Hakan Döneray16, Mehmet Nuri Özbek27, Mehmet Keskin28, Hasan Önal9, Nesibe Akyürek11, Kezban Bulan11, Derya Tepe12, Hamdi Cihan Emeksiz13, Korcan Demir14, Deniz Kızılay17, Ali Kemal Topaloğlu21, Erdal Eren20, Samim Ozen4, Hüseyin Demirbilek27, Saygın Abalı3, Leyla Akın9, Beray Selver

Eklioğlu11, Sultan Kaba18, Ahmet Anık26, Serpil Baş3, Tolga Ünüvar9, Halil Sağlam20,

Semih Bolu29, Tolga Özgen9, Durmuş Doğan20, Esra Deniz Çakır20, Yaşar Şen30, Nesibe Andıran12,31, Filiz Çizmecioğlu23, Olcay Evliyaoğlu22, Gülay Karagüzel25, Özgür Pirgon32, Gönül Çat|ı26, Hatice Dilek Can20, Fatih Gürbüz21, Çiğdem Binay24, Veysel Nijat Baş33, Celal Sağlam2, Davut Gül2, Adem Polat2, Cengizhan Açıkel2, Peyami Cinaz13

1/stanbul University Istanbul Faculty of Medicine, Department of Pediatric Endocrinology, Istanbul, Turkey ${ }^{2}$ Gülhane Military Medicine Academy, Department of Pediatric Endocrinology, Ankara, Turkey

3 Marmara University Faculty of Medicine, Department of Pediatric Endocrinology, Istanbul, Turkey ${ }^{4}$ Ege University Faculty of Medicine, Department of Pediatric Endocrinology, Izmir, Turkey

${ }^{5}$ Katip Çelebi University Faculty of Medicine, Department of Pediatric Endocrinology, Izmir, Turkey 6Konya Training and Research Hospital, Clinic of Pediatric Endocrinology, Konya, Turkey

7 On Dokuz Mayıs University Faculty of Medicine, Department of Pediatric Endocrinology, Samsun, Turkey 8 Erciyes University Faculty of Medicine, Department of Pediatric Endocrinology, Kayseri, Turkey

${ }^{9}$ Kanuni Sultan Süleyman Training and Research Hospital, Clinic of Pediatric Endocrinology, Istanbul, Turkey 10Inönü University Faculty of Medicine, Department of Pediatric Endocrinology, Malatya, Turkey

${ }^{11}$ Necmettin Erbakan University Faculty of Medicine, Department of Pediatric Endocrinology, Konya, Turkey

12 Yıldırım Beyazıt University Faculty of Medicine, Department of Pediatric Endocrinology, Ankara, Turkey ${ }^{13}$ Gazi University Faculty of Medicine, Department of Pediatric Endocrinology, Ankara, Turkey

${ }^{14}$ Dr. Behçet Uz Children Hospital, Clinic of Pediatric Endocrinology, Izmir, Turkey

15Pamukkale University Faculty of Medicine, Department of Pediatric Endocrinology, Denizli, Turkey

16 Atatürk University Faculty of Medicine, Department of Pediatric Endocrinology, Erzurum, Turkey

${ }^{17}$ Celal Bayar University Faculty of Medicine, Department of Pediatric Endocrinology, Manisa, Turkey

18 Yüzüncü Yıl University Faculty of Medicine, Department of Pediatric Endocrinology, Van, Turkey 19 Harran University Faculty of Medicine, Department of Pediatric Endocrinology, Şanliurfa, Turkey

20 Uludağ University Faculty of Medicine, Department of Pediatric Endocrinology, Bursa, Turkey

21 Çukurova University Faculty of Medicine, Department of Pediatric Endocrinology, Adana, Turkey

22Istanbul University Cerrahpaşa Faculty of Medicine, Department of Pediatric Endocrinology, Istanbul, Turkey

23 Kocaeli University Faculty of Medicine, Department of Pediatric Endocrinology, Kocaeli, Turkey

${ }^{24}$ Osmangazi University Faculty of Medicine, Department of Pediatric Endocrinology, Eskişehir, Turkey

${ }^{25}$ Karadeniz Technical University Faculty of Medicine, Department of Pediatric Endocrinology, Trabzon, Turkey

${ }^{26}$ Dokuz Eylül University Faculty of Medicine, Department of Pediatric Endocrinology, Izmir, Turkey

27Diyarbakır Training and Research Hospital, Clinic of Pediatric Endocrinology, Diyarbakır, Turkey

28 Gaziantep University Faculty of Medicine, Department of Pediatric Endocrinology, Gaziantep, Turkey

${ }^{29}$ Düzce University Faculty of Medicine, Department of Pediatric Endocrinology, Düzce, Turkey

${ }^{30}$ Selçuk University Faculty of Medicine, Department of Pediatric Endocrinology, Konya, Turkey

${ }^{31}$ Keçiören Training and Research Hospital, Clinic of Pediatric Endocrinology, Ankara, Turkey

32Süleyman Demirel University Faculty of Medicine, Department of Pediatric Endocrinology, Isparta, Turkey

${ }^{33}$ Kayseri Training and Research Hospital, Clinic of Pediatric Endocrinology, Kayseri, Turkey

Address for Correspondence

Ediz Yeşilkaya MD, Gülhane Military Medicine Academy, Department of Pediatric Endocrinology, Ankara, Turkey

Phone: +90 3123041898 E-mail: dredizyesilkaya@gmail.com

OJournal of Clinical Research in Pediatric Endocrinology, Published by Galenos Publishing 


\section{ABSTRACT}

Objective: Children with Turner syndrome (TS) have a specific growth pattern that is quite different from that of healthy children. Many countries have population-specific growth charts for TS. Considering national and ethnic differences, we undertook this multicenter collaborative study to construct growth charts and reference values for height, weight and body mass index (BMI) from 3 years of age to adulthood for spontaneous growth of Turkish girls with TS

Methods: Cross-sectional height and weight data of 842 patients with TS, younger than 18 years of age and before starting any therapy, were evaluated. Results: The data were processed to calculate the $3^{\text {rd }}, 10^{\text {th }}, 25^{\text {th }}, 50^{\text {th }}, 75^{\text {th }}$, $90^{\text {th }}$ and $97^{\text {th }}$ percentile values for defined ages and to construct growth curves for height-for-age, weight-for-age and BMl-for-age of girls with TS. The growth pattern of TS girls in this series resembled the growth pattern of TS girls in other reports, but there were differences in height between our series and the others.

Conclusion: This study provides disease-specific growth charts for Turkish girls with TS. These disease-specific national growth charts will serve to improve the evaluation of growth and its management with growth-promoting therapeutic agents in TS patients.

Key words: Turner syndrome, growth charts, body mass index charts, Turkish children

Conflict of interest: None declared

Received: 30.03 .2015

Accepted: 21.04 .2015

\section{Introduction}

Turner syndrome (TS) is a common chromosomal disorder occurring in 1:2500 female live births. The most common presenting symptom in girls with TS is short stature which is mild during early childhood but becomes more notable with age. Untreated females are reported to be approximately $18-20 \mathrm{~cm}$ shorter than the general population $(1,2,3,4)$.

Growth curves are widely used in pediatric practice and are very important tools for the evaluation of child health $(5,6,7,8,9)$. The curves proposed by international health organizations, such as the World Health Organization (10) and the Centers for Disease Control and Prevention (11), provide growth evaluation in children belonging to different ethnicities and socio-economic conditions. However, children with specific diseases (including TS) and having a specific growth pattern cannot be well assessed with the curves designed for healthy children. Thus, disease-specific growth charts are required for better evaluation of growth and response to growth-promoting therapies in certain diseases.

There are growth curves for girls with TS from different countries which are affected by ethnicity and genetic factors $(12,13,14,15,16,17,18,19,20,21,22,23,24)$. Preliminary studies have revealed that patients with TS have a high incidence of obesity. Weight-associated height references are therefore required in this area $(13,20,24,25)$. Currently, there are no population-specific growth standards that allow monitoring of the growth of Turkish TS patients of different ages or provide a basis for a fairly accurate prediction of their adult height.

We therefore undertook a collaborative study to construct growth charts and reference equations for agematched height, weight and body mass index (BMI) values from 3 years of age to adulthood for spontaneous growth of Turkish girls with TS.

\section{Methods}

This study on the evaluation of nationwide data of patients with TS in Turkey, the details of which have been reported previously, was conducted by the Turkish Turner Syndrome Study Group (26).

\section{Patients and Data Collection}

A total of 842 patients with TS, younger than 18 years of age, who presented to 35 different centers in Turkey between 1984 and 2014, were enrolled in this crosssectional study. The study was approved by the Ethics Committee of Gülhane Military Medical Academy.

A Case Recording Form (CRF) was created which contained data on height and weightat first admission. Physicians working in outpatient clinics for TS patients were asked to fill in these CRF forms. The data were collected by physicians who were chosen to be responsible for the registration at each center. The data were assessed by four physicians (EY, FD, ES and PC) experienced in TS and were uploaded to the online web registry system located in the web site www.favorsci.org by van expert on electronic CRF preparation (CA). Data entered in the registry was also checked for consistency by a research assistant (EY).

A standard 30-cell karyotype analysis from peripheral blood was made in all patients. The diagnosis of TS was confirmed by reviewing all the reported karyotypes of cultured peripheral blood lymphocytes. Karyotypes of patients were assigned to numerical, structural and both numerical and structural abnormalities by a geneticist (DG).

Height and weight measurements taken according to standard techniques and recorded at presentation were collected retrospectively. After excluding the patients who were younger than 3 years of age and those with a history of growthpromoting treatment (such as growth hormone, estrogen, oxandrolone), we enrolled a total of 717 patients in the study.

The height values were interpolated individually to the nearest of the defined ages by expressing the measured height values as standard deviation score (SDS) using the Turkish references for height. The weight measurements were interpolated to full age values using the same method as height-for-age (27). BMI was calculated by dividing the weight by the square height or length $\left(\mathrm{kg} / \mathrm{m}^{2}\right)$. The obtained reference curves for height-for-age, weight-for-age and BMI- 
for-age of girls with TS were compared with those of healthy Turkish girls (27). For each defined age, $3^{\text {rd }}, 10^{\text {th }}, 25^{\text {th }}, 50^{\text {th }}$, $75^{\text {th }}, 90^{\text {th }}$ and $97^{\text {th }}$ percentile values were calculated by a statistician (MMM). For the specific percentile line, age \pm 6 month data were taken.

\section{Statistical Analysis}

Construction of the centile curves was performed with the LMS Chart Maker Pro version 2.3 software program (The Institute of Child Health, London), which fits smooth centile curves to reference data using the LMS method. The smoothed centile curves of BMI were constructed by the LMS method. This method summarizes percentiles at each age based on the power of age-specific Box-Cox power transformations that are used to normalize data. These three quantities depend on age. The final curves of percentiles are produced by three smooth curves representing Lambda; skewness (L), Mu; median (M) and Sigma; coefficient of variation (S). The LMS transformation equation is: $X=M(1+L S z)^{1 / L} L \neq 0$ or $X=M \exp (S z) L=0$ where $X$ is the physical measurement and $z$ is the $z$-score that corresponds to the percentile. The key task of the transformation was to estimate parameters $\mathrm{L}, \mathrm{M}$ and $\mathrm{S}$. With estimates of $L, M$ and $S$, values of $X$ are connected to the values of $z$ through the above equation. The percentile is obtained from a normal distribution table where the z-score corresponds to the percentile of interest.

\section{Results}

Karyotype analyses of the patients are shown in Table 1. Half of the patients had a 45,X chromosome constitution. Other karyotypes were as follows: $10.8 \%, 10.1 \%$ and $9.5 \%$ for $45, X / 46, X X, 46, X, i(X q)$ and $45, X / 46, X, i(X q)$, respectively.

\section{Height-for-Age}

The $L, M, S$ values and percentile values, the height growth chart and the mean change in height SDS for Turkish girls with TS are shown in Table 2, Figures 1 and 2, respectively. The comparison of the mean height of TS girls with that of other nationalities and with an age-matched Turkish healthy population is shown in Figure 3.

All mean height values in TS patients were lower in comparison to the mean values of healthy girls. The mean height values from 3 years of age were lower than that of the general population and got lower by age. While height was under -2 SD at age 3 years, this decline got closer to -4 SD at about 13 years of age. From the age of 13 , we observed that there was an increase of approximately 2.5-3 $\mathrm{cm}$ per year in height without pubertal peak. Around the ages of 14-15, the height distribution showed that -1 SD and -2 SD values for Turner girls nearly equaled the -5 SD and $-6 \mathrm{SD}$ values for the age-matched healthy girls, respectively.

The mean height of Turkish girls with TS, computed at 18.0 years of age, was found to be $141.9 \pm 6.9 \mathrm{~cm}$ in this cohort study, representing a deficit of about $21.2 \mathrm{~cm}$ according to the population mean $(163.1 \pm 5.9 \mathrm{~cm})$.

Table 1. Distribution of Turner syndrome patients according to karyotype ( $n=842)$

\begin{tabular}{|l|l|l|l|l|}
\hline & Non-Mosaic & $\mathbf{n}(\%)$ & Mosaic & $\mathbf{n}(\%)$ \\
\hline Aneuploidy & $45, \mathrm{X}$ & $427(50.7)$ & $45, \mathrm{X} / 46, \mathrm{XX}$ & $91(10.8)$ \\
\hline & - & - & $45, \mathrm{X} / 47, \mathrm{XXX}$ & $13(1.5)$ \\
\hline & - & - & $45, \mathrm{X} / 46, \mathrm{XY}$ & $23(2.7)$ \\
\hline & - & - & $45, \mathrm{X} / 46, \mathrm{XX} / 47, \mathrm{XXX}$ & $7(0.8)$ \\
\hline & - & $427(50.7)$ & - & $134(15.9)$ \\
\hline Structural abnormality & $46, \mathrm{X}, \mathrm{I}(\mathrm{Xq})$ & $85(10.1)$ & $45, \mathrm{X} / 46, \mathrm{X}, \mathrm{i}(\mathrm{Xq})$ & $82(9.5)$ \\
\hline & $46, \mathrm{X}, \mathrm{del}(\mathrm{Xp})$ & $16(1.9)$ & $45, \mathrm{X} / 46, \mathrm{X}, \mathrm{r}(\mathrm{X})$ & $29(3.4)$ \\
\hline & $46, \mathrm{X}, \mathrm{del}(\mathrm{Xq})$ & $11(1.3)$ & $45, \mathrm{X} / 46, \mathrm{X}, \mathrm{didi}(\mathrm{Y})$ & $11(1.4)$ \\
\hline & $46, \mathrm{X}, \mathrm{r}(\mathrm{X})$ & $5(0.6)$ & $45, \mathrm{X} / 46, \mathrm{X},+\mathrm{mar}$ & $10(1.2)$ \\
\hline & 0 thers & $14(1.7)$ & 0 thers & $18(2.2)$ \\
\hline & - & $131(15.6)$ & - & $150(17.8)$ \\
\hline Total & - & $558(66.3)$ & - & $284(33.7)$ \\
\hline
\end{tabular}




\section{Weight-for-Age}

The $L, M, S$ values and percentile values, the weight growth chart and the mean change in weight SDS for the Turkish girls with TS are shown in Table 3, Figures 4 and 5, respectively. The mean weight of Turkish girls with TS as compared to the mean weight of healthy Turkish girls is shown in Figure 6. All mean weights at different ages were lower in comparison to healthy girls. Mean weight SDS values from 3 years of age were lower than those of the general population and gradually decreased by age. At ages 16-17 years, the mean weight-for-age of TS girls was lower than the reference $-2 \mathrm{SD}$, whereas thereafter, the weight distribution showed that $+2 \mathrm{SD}$ and -2 SD for Turner girls nearly approached the reference +1 $\mathrm{SD}$ and $-5 \mathrm{SD}$, respectively (27).

The 50th percentile of weight, computed at $18.0 \mathrm{y}$ of age, was $45.0 \mathrm{~kg}$ and below that of the healthy population in this cohort study.

\section{Body Mass Index-for-Age}

The BMI distributions of the Turkish girls with TS are shown in Table 4, Figures 7 and 8. The mean BMI of Turkish girls with TS as compared to the mean BMI of healthy Turkish girls is shown in Figure 9.

The mean BMI distribution for TS at 3 years of age nearly approached the mean of the reference population and gradually increased by age. We also observed a plateau after 6 years of age, whereas thereafter, it always remained higher than the reference ranges. The BMI distribution showed that the +1 SD for Turner girls nearly equals the +2 $\mathrm{SD}$ of the reference girls.

\section{Discussion}

This study presents the growth data and growth curves of Turkish TS children. Three important considerations led

\begin{tabular}{|c|c|c|c|c|c|c|c|c|c|c|c|c|c|}
\hline \multirow{2}{*}{$\begin{array}{l}\text { Age } \\
\text { (Years) }\end{array}$} & \multirow[b]{2}{*}{ n } & \multirow[b]{2}{*}{$\mathbf{L}$} & \multirow[b]{2}{*}{ M } & \multirow[b]{2}{*}{$S$} & \multicolumn{7}{|c|}{ Percentiles } & \multirow[b]{2}{*}{ Mean } & \multirow[b]{2}{*}{ SD } \\
\hline & & & & & $3 p$ & $10 p$ & $25 p$ & $50 p$ & $75 p$ & $90 p$ & $97 p$ & & \\
\hline 3 & 11 & 2.2 & 84.7 & 0.1 & 70.1 & 75.2 & 79.9 & 84.7 & 89.3 & 93.1 & 96.7 & 84.1 & 6.8 \\
\hline 4 & 21 & -0.1 & 91.2 & 0.1 & 79.9 & 83.3 & 86.9 & 91.2 & 95.8 & 100.2 & 104.7 & 91.7 & 6.3 \\
\hline 5 & 31 & -1.7 & 96.6 & 0.1 & 86.5 & 89.4 & 92.6 & 96.6 & 101.1 & 105.6 & 110.7 & 97.5 & 6.2 \\
\hline 6 & 32 & -2.2 & 101.4 & 0.1 & 91.9 & 94.6 & 97.6 & $\mid 101.4$ & 105.8 & 110.3 & 115.4 & 102.4 & 6.0 \\
\hline 7 & 51 & -2.3 & 106.1 & 0.1 & 96.7 & 99.4 & 102.4 & 106.1 & 110.3 & 114.6 & 119.5 & 107.0 & 5.8 \\
\hline 8 & 34 & -2.0 & 110.7 & 0.1 & 101.2 & 103.9 & 107.0 & 110.7 & 114.8 & 118.9 & 123.4 & 111.4 & 5.7 \\
\hline 9 & 61 & -1.5 & 115.1 & 0.1 & 105.4 & 108.3 & 111.4 & 115.1 & 119.1 & 123.1 & 127.4 & 115.7 & 5.6 \\
\hline 10 & 54 & -0.9 & 119.3 & 0.0 & 109.3 & 112.3 & 115.5 & 119.3 & 123.3 & 127.2 & 131.2 & 119.7 & 5.6 \\
\hline 11 & 72 & -0.2 & 123.2 & 0.0 & 112.7 & 115.9 & 119.3 & 123.2 & 127.2 & 131.0 & 134.9 & 123.5 & 5.7 \\
\hline 12 & 81 & 0.4 & 126.8 & 0.0 & 115.7 & 119.2 & 122.7 & $\mid 126.8$ & 130.9 & 134.6 & 138.4 & 126.9 & 5.8 \\
\hline 13 & 63 & 1.0 & 130.0 & 0.0 & 118.4 & 122.1 & 125.9 & 130.0 & 134.2 & 138.0 & 141.7 & 130.0 & 5.9 \\
\hline 14 & 65 & 1.6 & 133.0 & 0.0 & 120.7 & 124.7 & 128.7 & 133.0 & 137.3 & 141.1 & 144.7 & 132.9 & 6.1 \\
\hline 15 & 50 & 2.2 & 135.8 & 0.0 & 122.7 & 127.0 & 131.2 & 135.8 & 140.1 & 143.9 & 147.5 & 135.5 & 6.3 \\
\hline 16 & 45 & 2.7 & 138.2 & 0.0 & 124.4 & 129.1 & 133.6 & 138.2 & 142.7 & 146.4 & 150.0 & 137.8 & 6.5 \\
\hline 17 & 24 & 3.2 & 140.5 & 0.0 & 125.9 & 131.0 & 135.7 & 140.5 & 145.0 & 148.8 & 152.4 & 139.9 & 6.8 \\
\hline 18 & 22 & 3.7 & 142.7 & 0.0 & 127.3 & 132.7 & 137.7 & 142.7 & 147.2 & 151.0 & 154.5 & 141.9 & 6.9 \\
\hline
\end{tabular}




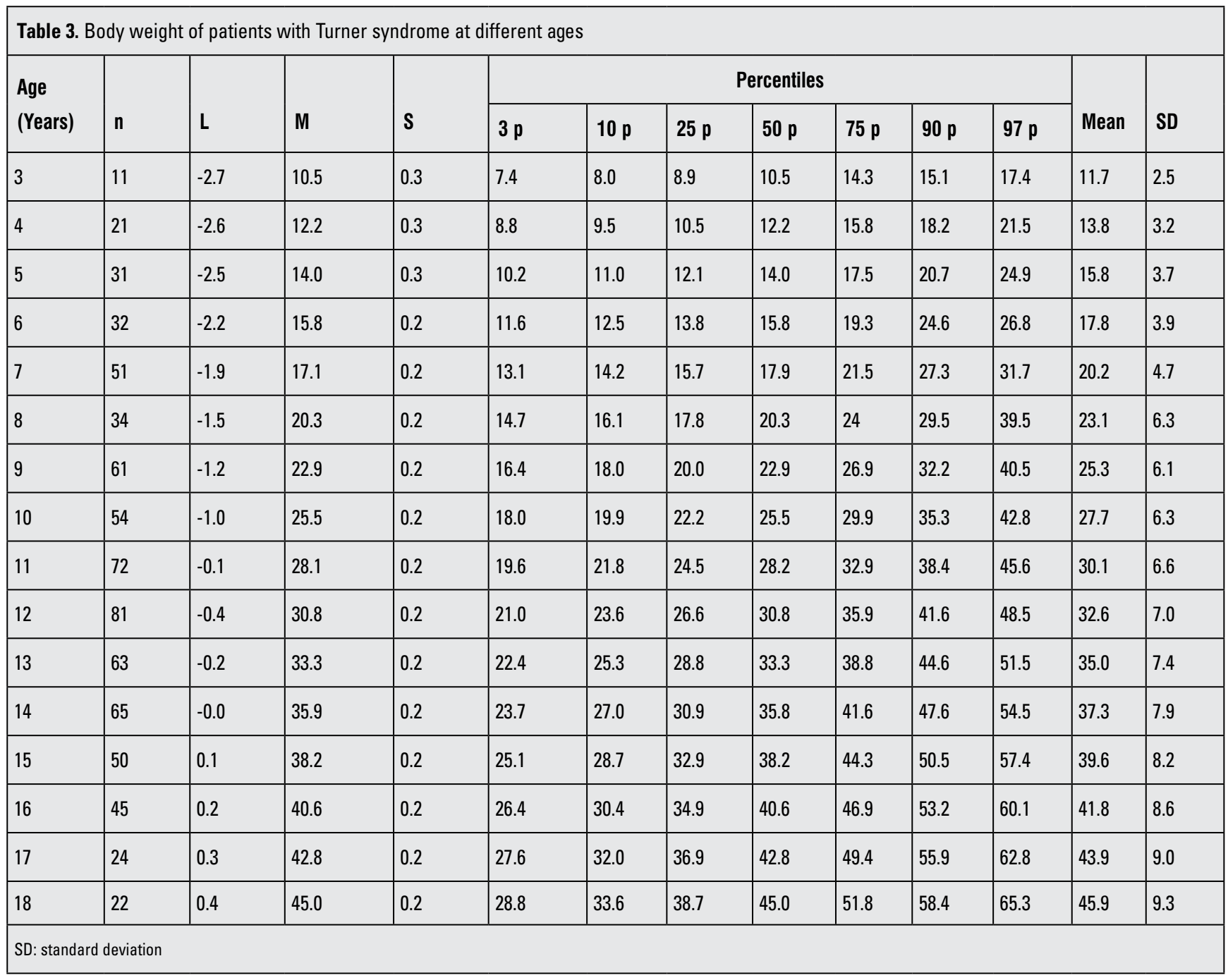
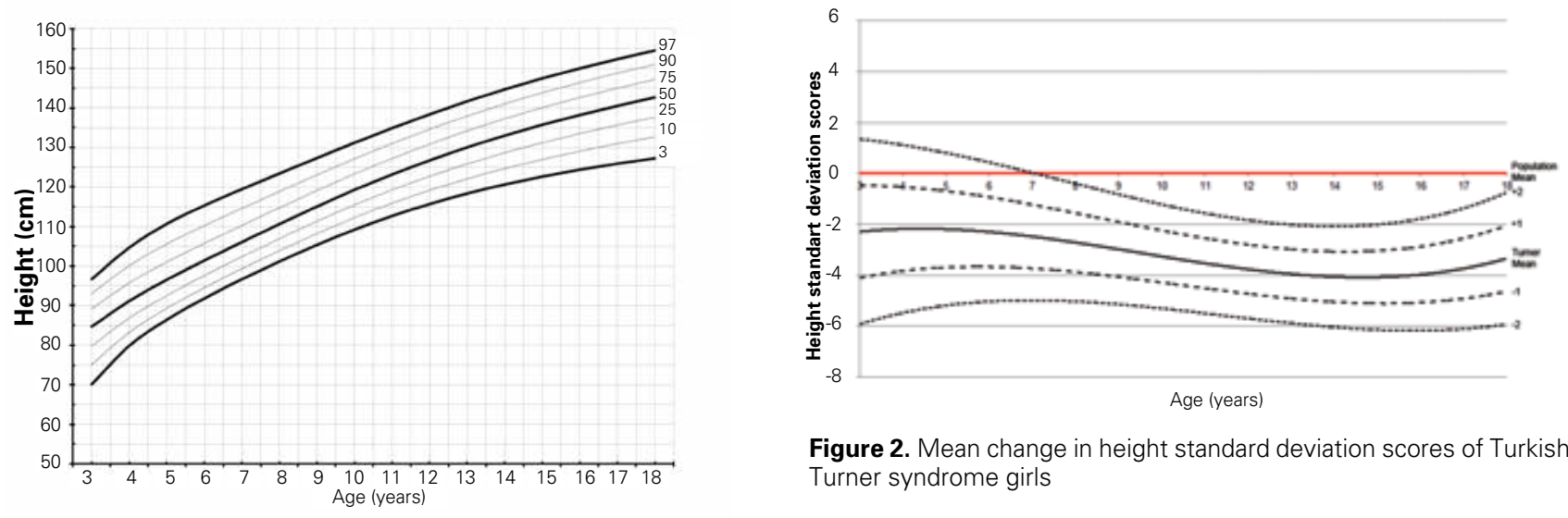

Figure 2. Mean change in height standard deviation scores of Turkish Turner syndrome girls

Figure 1. Height percentiles of Turkish Turner syndrome girls 
Table 4. Body mass index of patients with Turner syndrome at different ages

\begin{tabular}{|c|c|c|c|c|c|c|c|c|c|c|c|c|c|}
\hline \multirow{2}{*}{$\begin{array}{l}\text { Age } \\
\text { (Years) }\end{array}$} & \multirow{2}{*}{ n } & \multirow{2}{*}{$\mathbf{L}$} & \multirow{2}{*}{ M } & \multirow{2}{*}{$S$} & \multicolumn{7}{|c|}{ Percentiles } & \multirow{2}{*}{ Mean } & \multirow{2}{*}{ SD } \\
\hline & & & & & $3 p$ & $10 p$ & $25 p$ & $50 p$ & $75 p$ & $90 p$ & $97 p$ & & \\
\hline 3 & 11 & -1.4 & 15.5 & 0.1 & 13.4 & 14.0 & 14.6 & 15.5 & 16.4 & 17.4 & 18.6 & 15.7 & 1.3 \\
\hline 4 & 21 & -1.3 & 15.7 & 0.1 & 13.3 & 14.0 & 14.7 & 15.7 & 16.9 & 18.1 & 19.6 & 16.0 & 1.6 \\
\hline 5 & 31 & -1.1 & 15.8 & 0.1 & 13.0 & 13.8 & 14.7 & 15.8 & 17.2 & 18.6 & 20.3 & 16.2 & 1.9 \\
\hline 6 & 32 & -1.1 & 16.0 & 0.1 & 12.9 & 13.7 & 14.7 & 16.0 & 17.5 & 19.2 & 21.1 & 16.4 & 2.1 \\
\hline 7 & 51 & -1.0 & 16.3 & 0.1 & 12.9 & 13.9 & 14.9 & 16.3 & 18.1 & 19.9 & 22.2 & 16.9 & 2.4 \\
\hline 8 & 34 & -0.9 & 16.9 & 0.1 & 13.1 & 14.1 & 15.3 & 16.9 & 18.8 & 20.9 & 23.5 & 17.5 & 2.7 \\
\hline 9 & 61 & -0.9 & 17.5 & 0.2 & 13.4 & 14.5 & 15.8 & 17.5 & 19.6 & 21.9 & 24.8 & 18.2 & 2.9 \\
\hline 10 & 54 & -0.7 & 18.1 & 0.2 & 13.6 & 14.8 & 16.2 & 18.1 & 20.4 & 22.9 & 26.0 & 18.9 & 3.2 \\
\hline 11 & 72 & -0.6 & 18.7 & 0.2 & 13.9 & 15.2 & 16.7 & 18.7 & 21.1 & 23.8 & 27.0 & 19.5 & 3.3 \\
\hline 12 & 81 & -0.5 & 19.2 & 0.2 & 14.1 & 15.5 & 17.1 & 19.3 & 21.8 & 24.6 & 27.9 & 20.0 & 3.5 \\
\hline 13 & 63 & -0.4 & 19.8 & 0.2 & 14.3 & 15.8 & 17.5 & 19.8 & 22.5 & 25.3 & 28.6 & 20.5 & 3.6 \\
\hline 14 & 65 & -0.2 & 20.3 & 0.2 & 14.5 & 16.1 & 18.0 & 20.3 & 23.1 & 26.0 & 29.4 & 21.1 & 3.8 \\
\hline 15 & 50 & -0.2 & 20.8 & 0.2 & 14.8 & 16.4 & 18.4 & 20.8 & 23.7 & 26.7 & 30.1 & 21.6 & 3.9 \\
\hline 16 & 45 & -0.1 & 21.2 & 0.2 & 15.0 & 16.7 & 18.7 & 21.3 & 24.2 & 27.3 & 30.8 & 22.0 & 4.0 \\
\hline 17 & 24 & -0.1 & 21.7 & 0.2 & 15.2 & 17.0 & 19.1 & 21.7 & 24.8 & 27.9 & 31.5 & 22.5 & 4.2 \\
\hline 18 & 22 & -0.1 & 22.1 & 0.2 & 15.4 & 17.3 & 19.4 & 22.1 & 25.3 & 28.5 & 32.1 & 22.9 & 4.3 \\
\hline
\end{tabular}

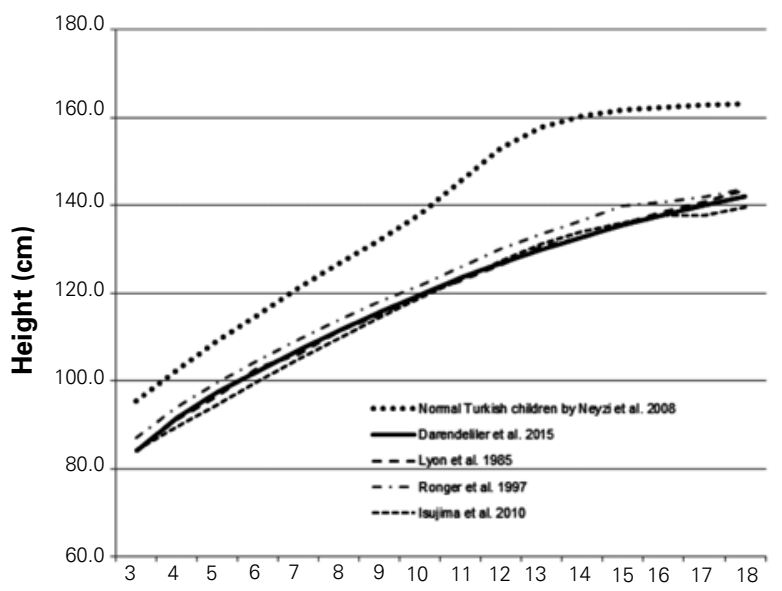

Figure 3. The comparison of the mean height of Turner syndrome girls with that of other nationalities and age-matched healthy Turkish children

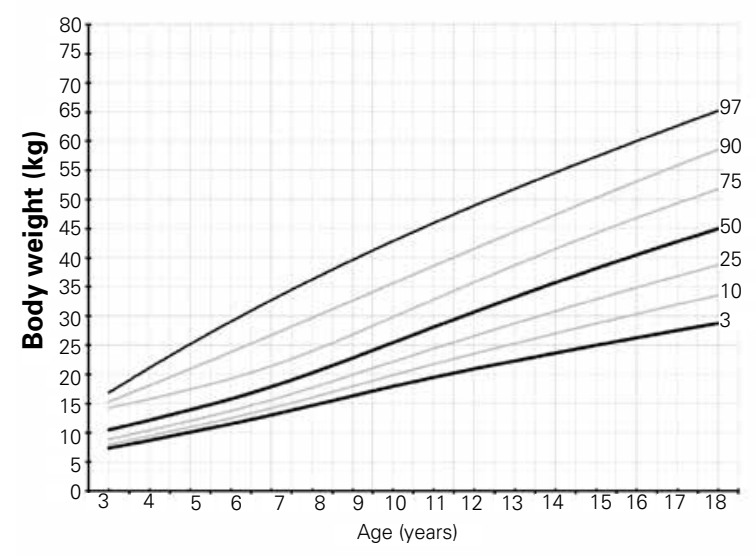

Figure 4. Body weight percentiles of Turkish Turner syndrome girls 


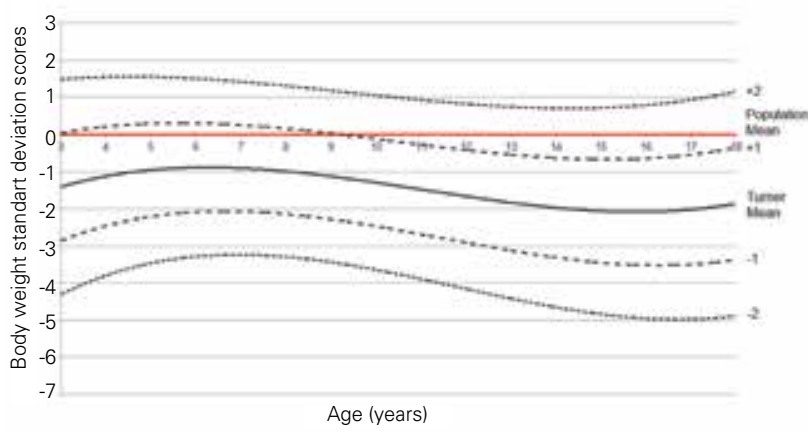

Figure 5. Mean change in weight standard deviation scores of Turkish Turner syndrome girls

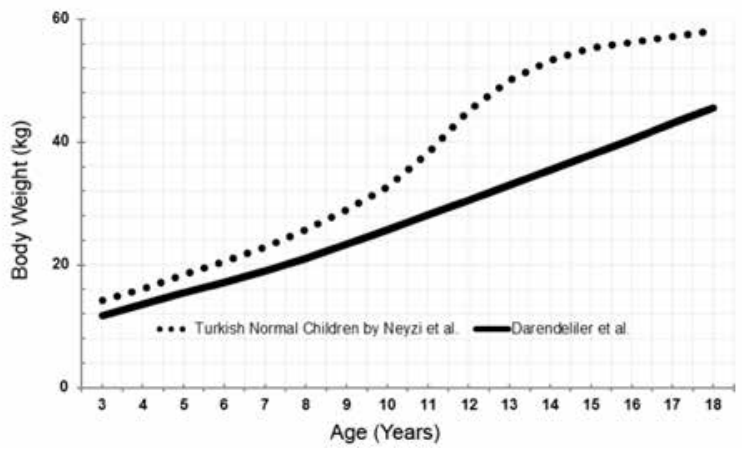

Figure 6. The comparison of the mean weight of Turkish Turner syndrome girls with the age-matched healthy population

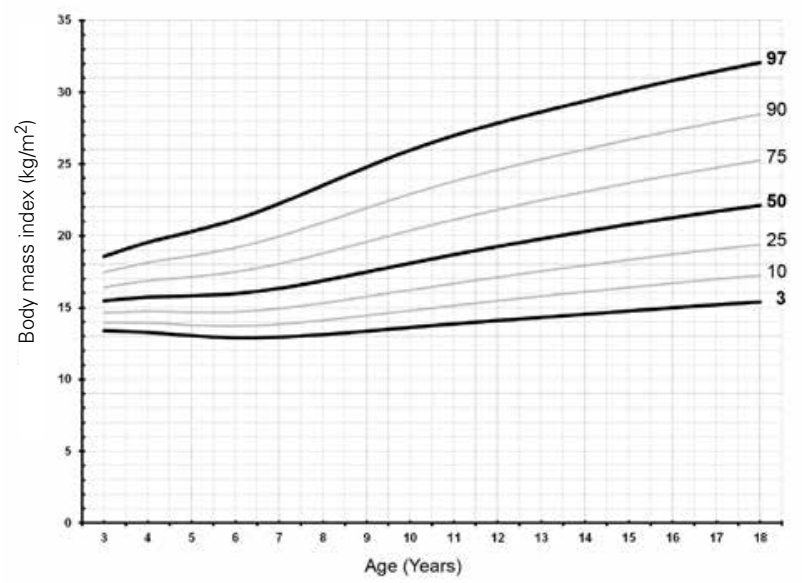

Figure 7. Body mass index percentiles of Turkish Turner syndrome girls

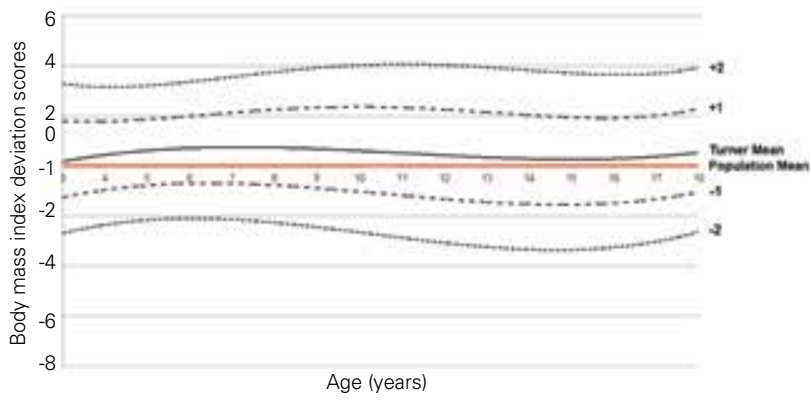

Figure 8. Mean change in body mass index standard deviation scores of Turkish Turner syndrome girls

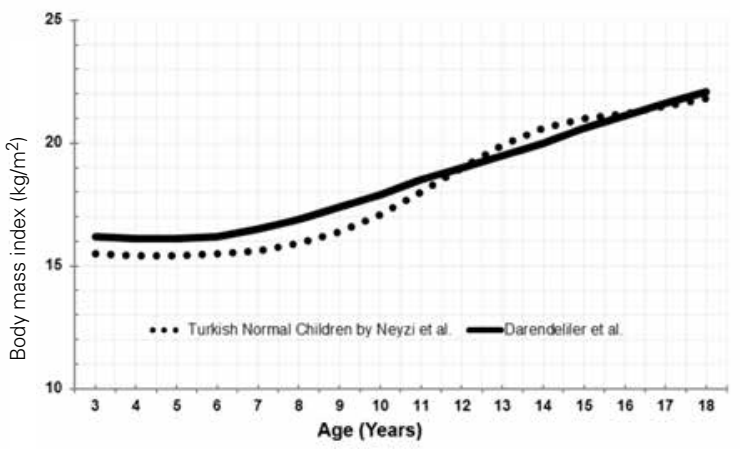

Figure 9. The comparison of the mean body mass index of Turkish Turner syndrome girls with the age-matched healthy population

us to realize the need for TS-specific growth charts for the children of our community.

Firstly, growth hormone (GH) and/or oestrogen, oxandrolone therapies, in addition to their favorable metabolic effects, are recommended to accelerate growth and final height in TS patients. However, supra-physiological GH dosages are usually necessary to induce height acceleration in these girls (28). The response to $\mathrm{GH}$ is rather variable depending on the different treatment protocols such as dosing regimens, adjuvant therapy with oxandrolone, age at start of GH therapy and management of puberty (29). Besides providing accurate information for the monitoring of growth in TS girls, TS-specific growth charts are also important in order to elucidate the response to growthpromoting therapies.

Secondly, many studies indicate that there may be associated autoimmune disorders such as Hashimoto thyroiditis and celiac disease that may further inhibit the growth of TS patients. Short stature and/or low growth velocity can be the primary or sole manifestation of these disorders. Thus, evaluating the growth pattern may also be helpful in establishing the early diagnosis and understanding 
Darendeliler F et al.

Growth Curves for Girls with Turner Syndrome

the pathogenesis of associated disorders which might influence growth $(30,31)$. The use of population-specific growth charts for the monitoring of growth in TS girls is therefore also recommended to detect the presence of an additional pathology (12).

Thirdly, girls with TS are prone to obesity because of excessive weight gain with a central or android fat distribution, particularly. This predisposition to obesity may be exaggerated in appearance by the characteristics of TS patients such as shield-like chest, stocky build and short stature with relatively short legs. The patients should be evaluated regularly with appropriate counseling to avoid obesity (32).

The growth pattern of patients with TS is characterized by intrauterine growth retardation, slow growth during the first three years of life, impaired pre-pubertal growth and lack of a pubertal growth spurt. In our cohort, the results indicated that height velocity declines after the first year of life progressively and is below -2 SD around 3-4 years of age. There is no significant pubertal growth spurt and the height SDS approaches -4 SD around age 12 years. However, the children continue to grow and reach a height SDS of -2.6 SD at 18 years of age. This further gain in height SD is also observed in patients without any pubertal development due to two possible reasons. Firstly, hormones other than gonadal steroids contribute to the normal pubertal growth spurt in girls. Secondly, there may be some residual function of the ovaries in Turner patients at the time of puberty and bone is more sensitive to estrogens than is breast tissue. The spurt in height growth often occurring as the first sign of puberty in normal girls is a finding which is in support of this latter theory $(14,29,33,34)$.

Ethnicity and genetic factors are important determinants of the growth curves for girls with TS. For instance, studies reveal that Japanese patients were shorter than the European patients (35). Therefore, country-specific growth curves should be generated. The comparison of our growth charts to two previously created percentile curves (by Lyon et al (16) and Rongen-Westerlaken et al (35)) revealed that the mean height percentile of our patients is almost identical to that reported by the first group of researchers but significantly lower than that reported by the second one.

Mean height at age 18 years was $141.9 \pm 6.9 \mathrm{~cm}$ in the present study. A previous study on 110 untreated Turkish Turner subjects reported a final height of $141.6 \pm 7.0 \mathrm{~cm}$ at 23 years of age (1). The slightly higher final height in the present study might reflect a secular trend or might be due to the small number of subjects of age 18 in our study.

BMI provides more information than weight-for-age and should be used as an index of adiposity in children. We constructed disease-specific charts for both weight-for-age and BMI in girls with TS. Several studies have shown that in general, the mean and SD values for weight in TS girls tend to increase with age. In our study, we observed that the distribution of BMI values gradually increased with age and that $a+1 S D$ value for Turner girls nearly equals a +2 SD value for the reference for normal Turkish girls. Further studies are needed to reveal which method is more effective in interpreting the relationship between weight and height in girls with TS. In this study, our results indicate that the mean SD value for BMI increased around 2 years of age and remained higher than the general population (35).

The limitation of our study is its cross-sectional design and we have no data regarding growth velocity and spontaneous pubertal status. Moreover, it is not known whether subjects showing no signs of puberty at the time of registration will develop spontaneous puberty later. This is an important topic, because preliminary studies revealed that those with spontaneous puberty, from 12 years of age onward, are significantly taller than those without puberty, although pubertal development and growth spurt do not seem to affect final adult height (7). Nevertheless, a longitudinal study on spontaneous growth in TS would not be possible for ethical reasons.

In conclusion, we have presented cross-sectional data on the spontaneous growth of a large number of Turkish girls with TS. These growth charts will be useful in following the natural growth, weight gain and also the growthpromoting effects of medical agents in these children.

\section{Acknowledgments}

We acknowledge Atilla Büyükgebiz, Heves Kırmızıbekmez, Gül Yeşiltepe Mutlu, Ihsan Esen for their contribution with one or two patients in the database. For technical support, we would like to thank the FAVOR Webbased registry system and its staff and also the Turkish Pediatric Endocrinology and Diabetes Society.

\section{Funding}

This work was supported by the Turkish Pediatric Endocrinology and Diabetes Society (Grand number: 012013).

\section{References}

1. Bereket A, Turan S, Elçioğlu N, Hacihanefioğlu S, Memioğlu $N$, Baş F, Bundak R, Darendeliler F, Günöz H, Saka N, Ercan O, Arslanoğlu I, Işgüven P, Yildiz M, Can S, Ozerkan E, Coker M, Darcan S, Ozkan B, Orbak Z, Oztaş S,Palandüz S, Sezgin I, Atabek E, Erkul I, Erdoğan G. Adult height in Turkish patients with Turner syndrome without growth hormone treatment. Turk J Pediatr 2008;50:415-417.

2. Davenport ML. Approach to the patient with Turner syndrome. J Clin Endocrinol Metab 2010;95:1487-1495.

3. Davenport ML. Growth hormone therapy in Turner syndrome. Pediatr Endocrinol Rev 2012;9:723-724.

4. Sybert VP, McCauley E. Turner's syndrome. N Engl J Med 2004;351:1227-1238. 
5. Bertapelli F, Barros-Filho Ade A, Antonio MÂA, Barbeta CJ, de Lemos-Marini SH, Guerra-Junior G. Growth curves for girls with Turner syndrome. Biomed Res Int 2014;2014:687978. Epub 2014 May 15

6. Garcia Rudaz C, Martínez AS, Heinrich JJ, Lejarraga $H$, Keselman A, Laspiur M, Bergadá C. Growth of Argentinian girls with Turner syndrome. Ann Hum Biol 1995;22:533-544.

7. Isojima T, Yokoya S, Ito J, Horikawa R, Tanaka T. New reference growth charts for Japanese girls with Turner syndrome. Pediatr Int 2009;51:709-714. Epub 2009 Mar 27

8. Isojima T, Yokoya S, Ito J, Naiki Y, Horikawa R, Tanaka T. Proposal of new auxological standards for Japanese girls with turner syndrome. Clin Pediatr Endocrinol 2010;19:6982. Epub 2010 Aug 31

9. Sempe M, Hansson Bondallaz C, Limoni C. Growth curves in untreated Ullrich-Turner syndrome: French reference standards 1-22 years. Eur J Pediatr 1996;155:862-869.

10. WHO Child Growth Standards: Length/Height-for-Age, Weight-for-Age, Weight-for-Length, Weight-for-Height and Body Mass Index-for-Age: Methods and Development. Geneva, Switzerland, World Health Organization; 2006.

11. Fryar CD, Gu Q, Ogden CL. Anthropometric Reference Data for Children and Adults: United States, 2007-2010. National Center for Health Statistics, Vital and Health Statistics, 2012.

12. Albertsson-Wikland K, Karlberg J. Natural growth in children born small for gestational age with and without catch-up growth. Acta Paediatr Suppl 1994;399:64-70.

13. Bernasconi S, Larizza D, Benso L, Volta C, Vannelli S, Milani S, Aicardi G, Berardi R, Borrelli P, Boscherini B. Turner's syndrome in Italy: familial characteristics, neonatal data, standards for birth weight and for height and weight from infancy to adulthood. Acta Paediatr 1994;83:292-298.

14. Haeusler G, Schemper M, Frisch H, Blümel P, Schmitt K, Plöchl E. Spontaneous growth in Turner syndrome: evidence for a minor pubertal growth spurt. Eur J Pediatr 1992;151:283-287.

15. Karlberg J, Albertsson-Wikland K, Nilsson KO, Ritzen EM, Westhpal O. Growth in infancy and childhood in girls with Turner syndrome. Acta Paediatr Scand 1991;80:158-165.

16. Lyon AJ, Preece MA, Grant DB. Growth curve for girls with Turner syndrome. Arch Dis Child 1985;60:932-935.

17. Massa G, Vanderschueren-Lodeweyckx M, Malvaux P. Linear growth in patients with Turner syndrome: influence of spontaneous puberty and parental height. Eur J Pediatr 1990;149:246-250.

18. Mazzanti L, Nizzoli G, Tassinari D, Bergamaschi R, Magnani C, Chiumello G, Cacciari E. Spontaneous growth and pubertal development in Turner's syndrome with different karyotypes. Acta Paediatr 1994;83:299-304.

19. Naeraa RW, Nielsen J. Standards for growth and final height in Turner's syndrome. Acta Paediatr Scand 1990;79:182190.

20. Ranke MB, Pfluger $H$, Rosendahl W, Stubbe P, Enders $H$, Bierich JR, Majewski F. Turner syndrome: spontaneous growth in 150 cases and review of the literature. Eur J Pediatr 1983;141:81-88.

21. Rochiccioli P, David M, Malpuech G, Colle M, Limal JM, Battin J, Mariani R, Sultan C, Nivelon JL, Simonin G. Study of final height in Turner's syndrome: ethnic and genetic influences. Acta Paediatr 1994;83:305-308.

22. Roede MJ, van Wieringen JC. Growth diagrams: 1980 Netherlands third nation-wide survey. Tijdschr Soc Gezondh 1985;63:1-34.
23. Rongen-Westerlaken C. Growth and growth hormone therapy in Turner syndrome. PhD Thesis. University of Utrecht, The Netherlands, 1991.

24. Suwa S. Standards for growth and growth velocity in Turner's syndrome. Acta Paediatr Jpn 1992;34:206-220.

25. Price DA, Albertsson-Wikland K. Demography, auxology and response to recombinant human growth hormone treatment in girls with Turner's syndrome in the Kabi Pharmacia International Growth Study. International Board of the Kabi Pharmacia International Growth Study. Acta Paediatr 1993;82(Suppl 391):69-74.

26. Yeşilkaya E, Bereket A, Darendeliler F, Baş F, Poyrazoğlu Ş, Küçükemre Aydın B, Darcan Ş, Dündar B,Büyükinan $M$, Kara C, Sarı E, Adal E, Akıncı A, Atabek ME, Demirel F, Çelik N, Özkan B, Özhan B, Orbak Z, Ersoy B, Doğan M, Ataş A, Turan S, Gökşen D, Tarım Ö, Yüksel B, Ercan O, Hatun Ş, Şimşek E, Ökten A, Abacı A,Döneray $H$, Özbek MN, Keskin M, Önal H, Akyürek N, Bulan K, Tepe D, Emeksiz HC, Demir K, Kızılay D, Topaloğlu AK, Eren E, Özen S, Abalı S, Akın L, Selver Eklioğlu B, Kaba S, Anık A, Baş S, Ünüvar T, Sağlam H, Bolu S, Özgen T, Doğan D, Deniz Çakır E, Şen Y, Andıran11 N, Çizmecioğlu F, Evliyaoğlu O, Karagüzel G, Pirgon Ö, Çatı G, Can HD, Gürbüz F, Binay Ç, Baş VN, Fidancı K, Polat A, Gül D, Açıkel C, Demirbilek H, Cinaz P, Bondy C. Turner syndrome and associated problems in Turkish children: A multicenter study. J Clin Res Pediatr Endocrinol 2015;7:27-36.

27. Neyzi $O$, Günöz $H$, Furman A, Bundak R, Gökçay G, Darendeliler F, Baş F. Türk çocuklarında vücut ağırlığı, boy uzunluğu, baş çevresi ve vücut kitle indeksi referans değerleri. Çocuk Sağlığı ve Hastalıkları Dergisi 2008;51:1-14.

28. Darendeliler F, Aycan Z, Cetinkaya E, Vidilisan S, Bas F, Bideci A, Demirel F, Darcan S, Buyukgebiz A, Yildiz M, Berberoglu M, Arslanoglu I, Bundak R. Effects of growth hormone on growth, insulin resistance and related hormones (ghrelin, leptin and adiponectin) in Turner syndrome. Horm Res 2007;68:1-7. Epub 2007 Jan 5

29. Sävendahl L, Davenport ML. Delayed diagnoses of Turner's syndrome: proposed guidelines for change. J Pediatr 2000:137:455-459.

30. Bonamico M, Scirè G, Mariani P, Pasquino AM, Triglione P, Scaccia S, Ballati G, Boscherini B. Short stature as the primary manifestation of monosymptomatic celiac disease. J Pediatr Gastroenterol Nutr 1992;14:12-16.

31. Dias Mdo C, Castro LC, Gandolfi L, Almeida RC, Córdoba MS, Pratesi R. Screening for celiac disease among patients with Turner syndrome in Brasília, DF, midwest region of Brazil. Arq Gastroenterol 2010;47:246-249.

32. Collett-Solberg PF, Gallicchio CT, Coelho SC, Siqueira RA, Alves ST, Guimarães MM. Endocrine diseases, perspectives and care in Turner syndrome. Arq Bras Endocrinol Metabol 2011;55:550-558.

33. Hjerrild $\mathrm{BE}$, Mortensen $\mathrm{KH}$, Gravholt $\mathrm{CH}$. Turner syndrome and clinical treatment. Br Med Bull 2008;86:77-93. Epub 2008 Apr 9

34. Low LC, Sham C, Kwan E, Karlberg J, Tang G, Cheung PT, Pang H, Tse W, But B, Yu CM, Lam ST. Spontaneous growth in Chinese patients with Turner's syndrome and influence of karyotype. Acta Paediatr 1997;86:18-21.

35. Rongen-Westerlaken C, Corel L, van den Broeck J, Massa G, Karlberg J, Albertsson-Wikland K, Naeraa RW, Wit JM. Reference values for height, height velocity and weight in Turner's syndrome. Swedish Study Group for GH treatment. Acta Paediatr 1997;86:937-942. 